\title{
EVALUATION OF THE ANTIMICROBIAL ACTIVITY OF Cinnamomum zeylanicum ESSENTIAL OIL AND trans-CINNAMALDEHYDE AGAINST RESISTANT Mycobacterium tuberculosis
}

\author{
AVALIAÇÃO DA ATIVIDADE ANTIMICROBIANA DO ÓLEO ESSENCIAL DO \\ Cinnamomum zeylanicum ESSENTIAL OIL E DO trans-CINAMALDEÍDO CONTRA \\ Mycobacterium tuberculosis RESISTENTE
}

\author{
Aquiles Paulino Peres MOTA ${ }^{1}$; Thales Alves CAMPELO ${ }^{1}$; Cristiane Cunha FROTA $^{1,2}$ \\ 1. Mycobacteria laboratory, Department of Pathology and Legal Medicine, Medicine School, Federal University of Ceará, Fortaleza, \\ CE, Brazil; 2. Ph.D. Professor, Federal University of Ceará, Fortaleza, CE, Brazil. cristianefrota71@gmail.com
}

\begin{abstract}
The essential oil (EO) extracted from the bark of Cinnamomum zeylanicum (Czey; also known as cinnamon), mostly derives its properties from its major compound trans-cinnamaldehyde (TCin). The present study evaluated the antimycobacterial activity of the essential oil from Czey (CzeyEO) and TCin against sensitive and resistant clinical isolates of Mycobacterium tuberculosis, as well as the combinatorial effects of CzeyEO and TCin with the anti-tuberculosis (TB) drugs rifampicin (RIF) and isoniazid (INH). The resazurin microtiter assay method was used to determine the minimum inhibitory concentration (MIC) of the components tested on the clinical isolates of $M$. tuberculosis. The effects of the CzeyEO/RIF, CzeyEO/INH, TCin/RIF, and TCin/INH combinations on the M. tuberculosis H37Rv reference strain were evaluated using the checkerboard method to determine the fractional inhibitory concentration index (FICI). CzeyEO and TCin inhibited all bacterial clinical isolates. In the interactive experiment, CzeyEO and TCin were found to be highly effective in reducing the resistance of resistant M. tuberculosis to RIF and INH. All four tested combinations demonstrated synergistic and additive effects, with no antagonistic effects. The synergistic combinations of CzeyEO/RIF and CzeyEO/INH exhibited FICI values of 0.375 and 0.5 , respectively, while the TCin/RIF and TCin/INH combinations exhibited FICI values of 0.31 and 0.5 , respectively. These results indicate that CzeyEO and TCin are potential candidates for the treatment of drug-resistant tuberculosis in combination therapy with INH and RIF.
\end{abstract}

KEYWORDS: Mycobacterium tuberculosis. Cinnamomum zeylanicum. trans- Cinnamaldehyde. Tuberculosis. Anti-bacterial agent.

\section{INTRODUCTION}

Tuberculosis (TB) is an infectious disease caused by the bacilli Mycobacterium tuberculosis. In 2016, an estimated 6.3 million new cases occurred worldwide, with approximately 1.4 million deaths from TB alone and 476,000 deaths from HIV-TB coinfection (WHO, 2017). Only $22 \%$ of the estimated global incidence in 2015 started with treatment for drug-resistant $\mathrm{TB}$ and $54 \%$ of them successfully completed the treatment.

The continued increase in mycobacterial resistance to drugs, often associated with treatment withdrawal, has hindered the effective control of TB globally. Disease control is especially difficult in the cases of multidrug-resistant TB, which consists of cases resistant to isoniazid (INH) and rifampicin (RIF) which are the two main anti-TB drugs in current use (WHO, 2017). Considering the increase in mycobacterial resistance to drugs, the development of new drugs is necessary, especially against multidrug-resistant strains (FONSECA et al., 2015). Consequently, medicinal plants through their essential oils (EOs) are considered promising alternatives for the development of new drugs. It is estimated that $25 \%$ of the currently used medications are derived directly or indirectly from medicinal plants (WALLIS et al., 2016). One of these medicinal plants that exhibit several biological activities is the Cinnamomum zeylanicum (Czey) species, popularly known as "cinnamon" or "Ceylon cinnamon". Trans-cinnamaldehyde (TCin) is the major component of the EO that is extracted from the bark of C. zeylanicum (CzeyEO).

Combination antimicrobial therapy is one of the alternatives for the treatment of infectious diseases caused by multidrug-resistant bacteria. These combinations of antimicrobial agents have been used for the treatment of TB and leprosy (PERRICONE et al., 2015). The analysis of antimicrobial activity of potential active substances and the use of double or triple combinations in in 
vitro studies demonstrated positive interactions capable of microorganism growth inhibition (ODDS, 2003).

Bioactivity against $M$. tuberculosis has already been demonstrated by the Egyptian Cinnamomum glanduliferum bark oil (TAHA; ELDAHSHAN, 2017), compounds of Cinnamomum kotoense (CHEN et al., 2005), and Cinnamomum verum essential oil and extract (ANDRADE-OCHOA et al., 2013; VAIDYA et al., 2016). Extracts and EOs of C. zeylanicum exhibit significant antimicrobial activities against several organisms, including the fungus Aspergillus (GOMEZ et al., 2018), M. tuberculosis (MOTA et al., 2018), gram-positive bacteria, (WIWATTANARATTANABUT et al., 2017), and gram-negative bacteria (LIU et al., 2017). The antibacterial activity of TCin has also been evaluated against several gram-negative bacteria (UTCHARIYAKIAT et al., 2016), gram-positive bacteria, (FERRO et al., 2016), and H37Rv strain of M. tuberculosis (ANDRADE-OCHOA et al., 2015; POLAQUINI et al., 2017). However, the antimycobacterial activities of CzeyEO and TCin have not been assessed against sensitive and resistant clinical isolates of $M$. tuberculosis. The antimycobacterial potential of these compounds also has not been studied. Furthermore, the interactions of CzeyEO and TCin with anti-TB drugs have not been determined. In this context, we evaluated the antibacterial properties of CzeyEO and TCin against clinical isolates of $M$. tuberculosis with different resistance profiles, as well as the effects of combinations of CzeyEO and TCin with INH and RIF.

\section{MATERIAL AND METHODS}

\section{Chemicals}

Isoniazid (purity $\geq 99 \%$ ), rifampicin (purity $\geq 97 \%$ ), trans-cinnamaldehyde (purity $=99 \%$ ), Tween ${ }^{\circledR} 80$ (purity $\sim 70 \%$ ), resazurin sodium salt (purity 80\%), and Middlebrook ADC growth supplement were acquired from Sigma-Aldrich (São Paulo, SP, Brazil). Difco ${ }^{\mathrm{TM}}$ Middlebrook 7H9 broth base was procured from Becton-Dickinson Biosciences (Franklin Lakes, USA). LowensteinJensen (LJ) medium was purchased from Newprov (Pinhais, Brazil). All chemicals and reagents used were of analytical grade.

\section{Collection and processing of materials for study}

The bark samples of $C$. zeylanicum were obtained from the local herb market of Fortaleza, Ceará, Brazil. The samples were stored at the
Federal University of Ceará Herbarium. A modified Clevenger apparatus was employed to extract the EOs, as previously described (OKOH et al., 2011). Essential oil yield (wt/wt \%) from the bark was then calculated.

Characterization of essential oil by gas
chromatography-mass spectrometry (GC-MS)
GC-MS was performed to analyze and identify the EO components. The GC-MS conditions were programmed as previously described (ADAMS, 2004), using a GCMS-QP2010 Ultra mass spectrometer (SHIMADZU, Shimadzu do Brasil, Barueri, Brazil). Parameters specific to the GC-MS were as follows: 5\% phenyl 95\% dimethylpolysiloxane column: capillary, $30 \mathrm{~m} \times$ $0.25 \mathrm{~mm}$ internal diameter (i.d.), purge flow $30 \mathrm{~mL} / \mathrm{min}$, purge time $0.20 \mathrm{~min}$, helium gas; temperature gradient of $4^{\circ} \mathrm{C} / \mathrm{min}\left(50^{\circ} \mathrm{C}\right.$ to $\left.280^{\circ} \mathrm{C}\right)$, inlet: splitless, initial temperature $250^{\circ} \mathrm{C}$. Electron energy of $70 \mathrm{eV}$ was used. The identification of each component was carried out through the agreement of their mass spectral data with the reference from the National Institute of Standards and Technology Mass Spectrometry database.

\section{Mycobacterial isolates and growth conditions}

A sensitive reference $\mathrm{H} 37 \mathrm{Rv}$ strain and nine clinical isolates from the laboratory stock of Dr. Carlos Alberto Studart Gomes Hospital, Fortaleza, Ceará, Brazil, were used for the antibacterial test.

All mycobacterial clinical isolates previously confirmed using the BACTEC $460 \mathrm{~TB}$ System (Becton-Dickinson Biosciences) were tested against CzeyEO, TCin, RIF, and INH following Clinical \& Laboratory Standards Institute (CLSI) guidelines (CLSI, 2011). The mycobacterial strains included three drug-sensitive and six multidrug resistant clinical isolates (four strains were RIF- and INH-resistant and two were RIF-, INH-, ethambutol-, and streptomycin-resistant). The minimum inhibitory concentration (MIC) of the essential oils and controls was determined.

The bacterial isolates were grown on $\mathrm{LJ}$ medium for 21 days at $37^{\circ} \mathrm{C}$. Inocula were prepared from the LJ medium through suspension in saline solution containing $0.04 \%$ (vol/vol) Tween ${ }^{\circledR} 80$ and $0.2 \%$ bovine albumin. The bacterial suspension was further diluted into $7 \mathrm{H} 9$ broth to a concentration of approximately $3 \times 10^{8}$ colony-forming units (CFU)/mL (1.0 McFarland). The final inoculum concentration of $3 \times 10^{7} \mathrm{CFU} / \mathrm{mL}$ was then achieved by $1: 10$ dilution into $7 \mathrm{H} 9$ broth, using $100 \mu \mathrm{L}$ inoculum. 


\section{MIC evaluation}

The resazurin microtiter assay method was performed to evaluate the MICs as described previously (FRANZBLAU et al., 1998; PALOMINO et al., 2002). All antimycobacterial assays with the reference strain and clinical isolates were performed in triplicates.

The CzeyEO and TCin solutions were diluted in distilled water containing $1 \%$ Tween ${ }^{\circledR} 80$ to a concentration of $1,250 \mu \mathrm{g} / \mathrm{mL}$. INH and RIF solutions were prepared at concentrations of 4.0 $\mu \mathrm{g} / \mathrm{mL}$ in distilled water and $8.0 \mu \mathrm{g} / \mathrm{mL}$ in methanol, respectively, and were filter-sterilized and kept frozen until use. Resazurin sodium salt powder was prepared at $0.02 \%(\mathrm{wt} / \mathrm{vol})$ in distilled water and filter-sterilized. It could be stored at $4{ }^{\circ} \mathrm{C}$ for one week.

Aliquots $(100 \mu \mathrm{L})$ of CzeyEO, TCin, INH, and RIF solutions were added to each well containing 7H9 media. Serial two-fold dilutions of each oil and drug in $100 \mu \mathrm{L}$ of $7 \mathrm{H} 9$ medium were prepared directly in 96-well plates at concentrations ranging from $312 \mu \mathrm{g} / \mathrm{mL}$ to $2.44 \mu \mathrm{g} / \mathrm{mL}$ for CzeyEO and TCin, respectively, 1.0 to $0.07 \mu \mathrm{g} / \mathrm{mL}$ for $\mathrm{INH}$, and 2.0 to $0.0015 \mu \mathrm{g} / \mathrm{mL}$ for RIF. Growth controls without antibacterial agents and sterility controls without bacterial inoculation were also included. The plates were then covered, sealed, and incubated at $37^{\circ} \mathrm{C}$. After 7 days of incubation, $30 \mu \mathrm{L}$ of resazurin solution was added to each well, incubated at $37^{\circ} \mathrm{C}$ for 24 to $48 \mathrm{~h}$, and assessed for color development. The blue dye resazurin is irreversibly reduced to a pink-colored resorufin in the presence of viable bacterial cells. Where bacterial growth was inhibited, the solution in the well remained bluish after incubation with the dye. The lowest concentration that exhibited blue color was defined as the MIC.

\section{The checkerboard method}

The study of the interaction of CzeyEO and TCin with RIF and INH was conducted using the checkerboard method (ROSATO et al., 2007; LECHARTIER et al., 2012). Two-fold serial dilutions of each drug prepared in horizontal rows of a 96-well microtiter plate were subsequently crossdiluted vertically by two-fold serial dilutions of EO and TCin. Microtiter plates were inoculated with the M. tuberculosis $\mathrm{H} 37 \mathrm{Rv}$ reference strain and incubated for 7 days at $37^{\circ} \mathrm{C}$ as described above. MIC values were also determined as described above. Interaction between the EO and each drug was then determined by calculating the fractional inhibitory concentration index (FICI). The FICI is defined as follows: (MIC of substance " $\mathrm{A}$ " tested in combination/MIC of substance "A" tested alone) +
(MIC of substance "B" tested in combination/MIC of substance " $\mathrm{B}$ " tested alone). The FICI is interpreted as follows: FICI $\leq 0.5$, synergistic effect; $0.5<$ FIC $\leq 1$, additive effect $1<$ FICI $\leq 4$, indifferent effect; and FIC $>4$, antagonistic effect. The synergistic effect is shown graphically by applying the isobole method.

\section{Statistical analysis}

The experimental data are expressed as mean \pm standard deviation $( \pm$ SD) from three independent experiments. GraphPad Prim 7 software was used to build the isobolograms.

\section{Ethics}

This study was approved by the institutional review board of the Ethical Committee of Federal University of Ceará, Fortaleza, CE, Brazil (Approval number: 1292579). Guidelines of the Ethical Committee were followed during the research.

\section{RESULTS}

The EO yield (w/w\%) of C. zeylanicum was $0.13 \%$. CzeyEO was analyzed by gas chromatography-mass spectrometry (GC-MS) and 12 components were identified, representing 100\% of the EO. The main components were Tcin $(86 \%)$, cinnamic acetate $(5.46 \%), \alpha$-pinene $(1.76 \%)$, and eucalyptol (1.65\%).

The in vitro antibacterial activity of CzeyEO, TCin, RIF, and INH against the tested mycobacteria was determined by the presence or absence of growth and by MIC values. As shown in Table 1, INH and RIF exhibited lower MICs $(0.125$ and $0.06 \mu \mathrm{g} / \mathrm{mL}$, respectively) than CzeyEO and TCin $(19.5 \mu \mathrm{g} / \mathrm{mL})$ against the reference $M$. tuberculosis $\mathrm{H} 37 \mathrm{Rv}$ strain. In the clinical isolates, the mean MIC of CzeyEO was $21.7 \mu \mathrm{g} / \mathrm{mL}( \pm 6.5$ $\mu \mathrm{g} / \mathrm{mL}$ ), whereas the mean MIC of TCin was 15.2 $\mu \mathrm{g} / \mathrm{mL}( \pm 5.1 \mu \mathrm{g} / \mathrm{mL})$ (Table 1 and Figure 1).

In this study, we evaluated the synergistic potential of CzeyEO and its main component, TCin, when used in combination with INH and RIF against the reference $M$. tuberculosis H37Rv strain using the checkerboard method (Figure 2). Two dilutions of the CzeyEO and INH combination against the reference strain resulted in synergism and they exhibited FICI of 0.375 and 0.5 . Moreover, this observation was similar to that of the CzeyEO and RIF combination. The additive effects were observed in five dilutions (FICI of 0.56 to 1.0). The lower FICI value represented an eight-fold reduction 
in the MIC of the RIF and INH combination and $\mathrm{s}$

four-fold reduction in the MIC of CzeyEO.

Table 1. Antibacterial activity of isoniazid (INH), rifampicin (RIF), streptomycin (SM), and ethambutol (EMB) drugs against $M$. tuberculosis isolates and minimum inhibitory concentrations (MICs) of CzeyEO and $\mathrm{TC}$ in $(\mu \mathrm{g} / \mathrm{mL})$.

\begin{tabular}{|c|c|c|c|c|c|c|c|c|}
\hline \multirow{2}{*}{ M. tuberculosis Strains } & \multicolumn{4}{|c|}{ Sensitivity profile $^{*}$} & \multicolumn{4}{|c|}{ MIC $(\mu \mathrm{g} / \mathrm{mL})$} \\
\hline & INH & RIF & SM & EMB & INH & RIF & CzeyEO & TCin \\
\hline Reference H37Rv & $\mathrm{S}$ & $\mathrm{S}$ & $\mathrm{S}$ & $\mathrm{S}$ & 0.125 & 0.06 & 19.5 & 19.5 \\
\hline \multicolumn{9}{|l|}{ Clinical isolates: } \\
\hline 1 & $\mathrm{~S}$ & $\mathrm{~S}$ & $\mathrm{~S}$ & $\mathrm{~S}$ & & & 19.5 & 19.5 \\
\hline 2 & $\mathrm{~S}$ & $\mathrm{~S}$ & $\mathrm{~S}$ & $\mathrm{~S}$ & & & 19.5 & 9.75 \\
\hline 3 & $\mathrm{~S}$ & $\mathrm{~S}$ & $\mathrm{~S}$ & $\mathrm{~S}$ & & & 39.0 & 19.5 \\
\hline 4 & $\mathrm{R}$ & $\mathrm{R}$ & $\mathrm{S}$ & $\mathrm{S}$ & & & 19.5 & 9.75 \\
\hline 5 & $\mathrm{R}$ & $\mathrm{R}$ & $\mathrm{S}$ & $\mathrm{S}$ & & & 19.5 & 19.5 \\
\hline 6 & $\mathrm{R}$ & $\mathrm{R}$ & $\mathrm{S}$ & $\mathrm{S}$ & & & 19.5 & 9.75 \\
\hline 7 & $\mathrm{R}$ & $\mathrm{R}$ & $\mathrm{S}$ & $\mathrm{S}$ & & & 19.5 & 19.5 \\
\hline 8 & $\mathrm{R}$ & $\mathrm{R}$ & $\mathrm{R}$ & $\mathrm{R}$ & & & 19.5 & 9.75 \\
\hline 9 & $\mathrm{R}$ & $\mathrm{R}$ & $\mathrm{R}$ & $\mathrm{R}$ & & & 19.5 & 19.5 \\
\hline Mean & & & & & & & 21.7 & 15.2 \\
\hline SD & & & & & & & \pm 6.5 & \pm 5.1 \\
\hline
\end{tabular}

S: susceptible; R: resistant; CzeyEO: essential oil of C. zeylanicum; TCin: trans-Cinnamaldehyde; SD: standard deviation. ${ }^{*}$ antibacterial activity determined using CLSI guidelines (CLSI, 2011).

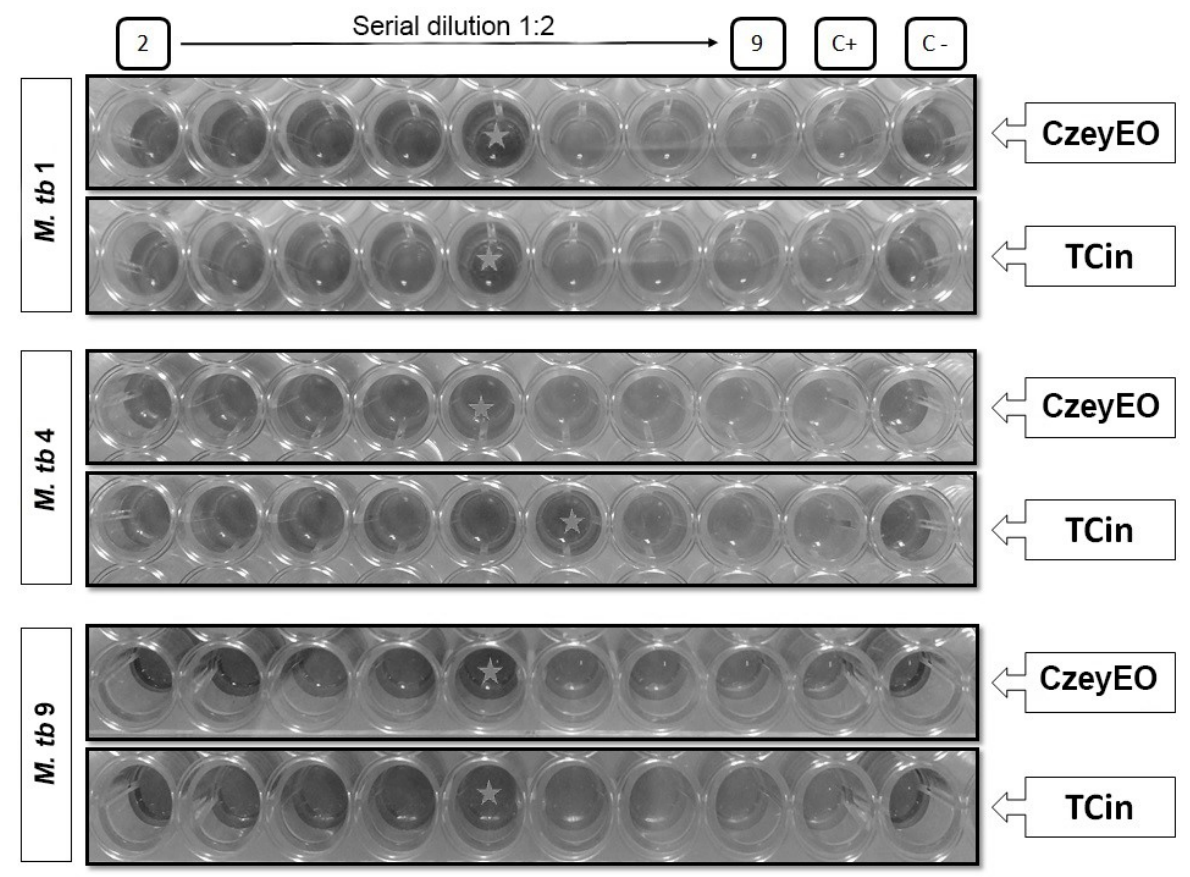

Figure 1. Antibacterial activity by resazurin microtiter assay of CzeyEO and TCin against three clinical isolates of M. tuberculosis and minimum inhibitory concentrations (MICs) expressed in $\mu \mathrm{g} / \mathrm{mL}$. The darker wells indicate bacterial growth. The white stars indicate the MIC, the lowest concentration with bacterial growth. The $\mathrm{C}+$ column indicates the positive growth control. The $\mathrm{C}$ - column indicates no growth of the negative control. The 2 and 9 indicate the numbers of the plate column. Mtb 1, Mtb 4, and Mtb 9 are M. tuberculosis clinical isolates. CzeyEO: C. zeylanicum essential oil, TCin: transCinnamaldehyde. 

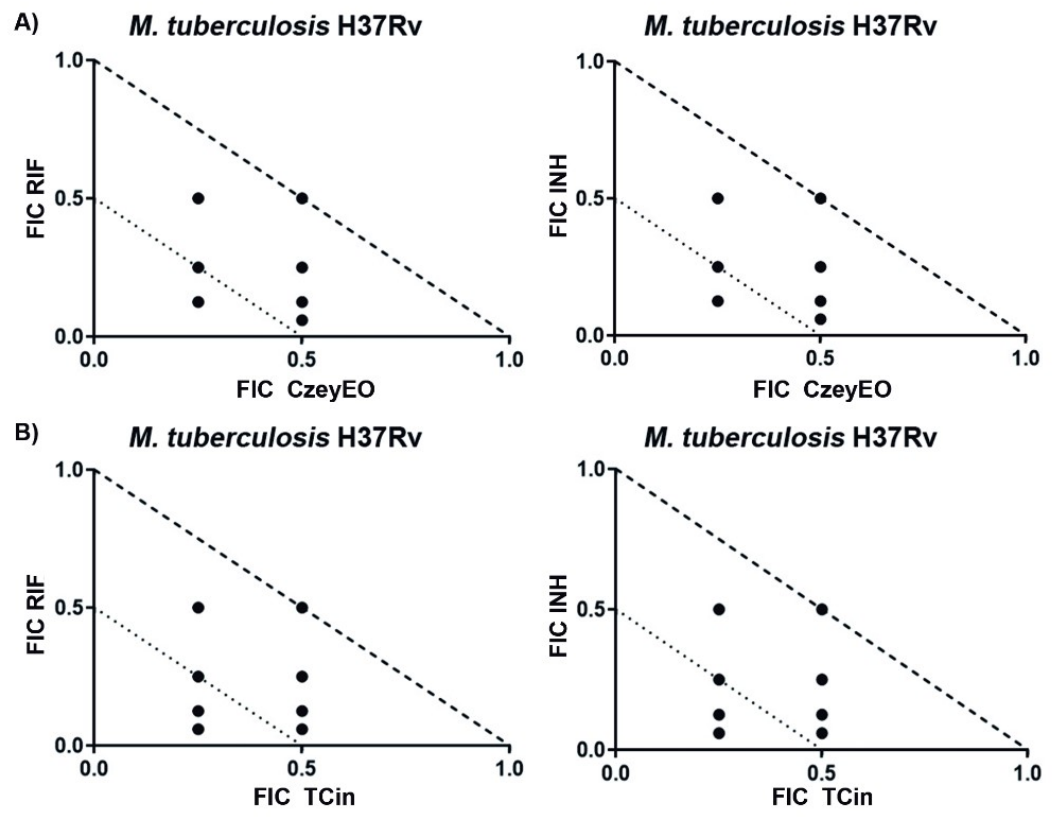

Figure 2. Isobologram showing the synergistic effect of C. zeylanicum EO and Tcin with isoniazid and rifampicin drugs against the reference strain M. tuberculosis H37Rv. Fractional inhibitory concentration index (FICI) is indicated by black dots. Additive effect is indicated by dots between the dotted line (FICI $>0.5)$ and the dashed line (FICI $\leq 1.0)$. Synergistic effect is indicated by dots situated below the dotted line (FICI $\leq 0.5)$. A) Isobolograms for C. zeylanicum essential oil; B) Isobolograms for trans-Cinnamaldehyde. RIF: rifampicin, INH: isoniazid, CzeyEO: C. zeylanicum essential oil, TCin: trans-Cinnamaldehyde.

Similar to what was observed with CzeyEO, TCin interacted with RIF and INH, resulting in a synergistic effect in three dilutions against $M$. tuberculosis $\mathrm{H} 37 \mathrm{Rv}$ strain (FICI ranging from 0.31 to 0.5 ) and an additive effect in five dilutions (FICI ranging from 0.56 to 1.0 ). Of all the observed FICI values, the lowest value represented a sixteen-fold reduction in the MIC of the RIF and INH combination and a four-fold reduction in the MIC of TCin.

\section{DISCUSSION}

The results obtained for the chemical characterization of CzeyEO by GC-MS were similar to those found by other authors, who reported the characteristic presence of TCin as the main component, although there were differences in the observed concentrations (RAVINDRAN et al., 2003; ANDRADE et al., 2012). In addition, we found synergistic association of TCin and CzeyEO with RIF and INH against sensitive and resistant $M$. tuberculosis clinical isolates.

The differences in the observed concentrations among different studies can be attributed to differences in extraction methodology, environmental variations (soil, humidity, temperature, and climate), physiological variations of the plant (evolutionary cycle, growth phase, and stress conditions), and genetic factors (BAKKALI et al., 2008).

CzeyEO and TCin exhibited high antimycobacterial activity and were able to inhibit the growth of all clinical isolates of M. tuberculosis. Similar results were found in another study with CzeyEO inhibiting the growth of clinical isolates of $M$. tuberculosis with different resistance profiles, with MICs ranging from 12.5 to $25 \mu \mathrm{g} / \mathrm{mL}$ (ANDRADE-OCHOA et al., 2013). The same authors, in a subsequent study (ANDRADEOCHOA et al., 2015), observed that TCin was also able to inhibit the growth of $M$. tuberculosis at a concentration of $3.12 \mu \mathrm{g} / \mathrm{mL}$ and of $M$. bovis at a concentration of $12.5 \mu \mathrm{g} / \mathrm{mL}$.

It has been observed that the strains of gram-negative bacteria are more resistant to EOs in vitro compared to strains of gram-positive bacteria (RANA et al., 2011). This is similar to the characteristics of mycobacteria, which have high lipid content in their cell walls, conferring low permeability and resistance to hydrophilic agents (HOFFMANN et al., 2008; FORRELLAD et al., 2013). 
The results obtained for the sensitivity of MICs of INH and RIF against the reference $M$. tuberculosis $\mathrm{H} 37 \mathrm{Rv}$ strain were similar to those described in the literature, as the breakpoint concentrations for resistance to INH and RIF are $0.25 \mu \mathrm{g} / \mathrm{mL}$ and $0.5 \mu \mathrm{g} / \mathrm{mL}$, respectively (SINGH et al., 2012). Our MIC results demonstrated lower breakpoint concentrations for resistance to INH and RIF (0.125 and $0.06 \mu \mathrm{g} / \mathrm{mL}$, respectively). Other authors reported an MIC of $0.06 \mu \mathrm{g} / \mathrm{mL}$ for INH and RIF against $M$. tuberculosis H37Rv strain (CAMACHO-CORONA et al., 2008). Similarly, low MICs of $0.05 \mu \mathrm{g} / \mathrm{mL}$ for INH and $0.03 \mu \mathrm{g} / \mathrm{mL}$ for RIF have been reported (KASULE et al., 2016).

Studies of synergistic and additive activities of EOs and their active components with drugs against several microorganisms have been reported, but there are a few reports of these interactions on M. tuberculosis (RASTOGI et al., 1998; CHEN et al., 2011; JIMENEZ-ARELLANES et al., 2013; NAIK et al., 2014; ARO et al., 2016).

Previous studies demonstrated a synergistic activity of trans-cinnamic acid with antimycobacterial drugs against sensitive and resistant $M$. tuberculosis clinical isolates (RASTOGI et al., 1998; CHEN et al., 2011). In rats and mice, TCin has been shown to be metabolize into cinnamic acid, an active metabolite against $M$. tuberculosis (NATIONAL TOXICOLOGY, 2004).

We compared the MIC values of the components tested in our study on the clinical isolates of M. tuberculosis and observed that TCin exhibited higher inhibitory activity as compared to CzeyEO. Likewise, we observed that in the test for synergism, the interactions were more effective with TCin compared to those with CzeyEO. Our findings corroborate the study carried out in Mexico that found no difference in the MIC values of CzeyEO between the different resistant clinical isolates of $M$. tuberculosis and the standard $\mathrm{H} 37 \mathrm{Rv}$ strain (ANDRADE-OCHOA et al., 2015).

Our results suggest that the inhibitory activity of CzeyEO on M. tuberculosis is attributed mainly, but not exclusively, to its major component, TCin. Other components, including some terpenes-which exhibit antibacterial activity against $M$. tuberculosis (ANDRADE-OCHOA et al., 2015) - present in CzeyEO also possess antibacterial activity that has been previously reported in the literature (RANA et al., 2011). The synergistic effect has also been reported in the association of $\alpha$-pinene with limonene in $S$. cerevisiae, which are also identified in CzeyEO (BASSOLE et al., 2011).
The MIC values found in our study for CzeyEO and TCin against the sensitive clinical isolates were similar to those of the clinical isolates resistant to the tested drugs [INH, RIF, streptomycin (SM), and ethambutol (EMB)]. Therefore, we propose that the mechanism of action of CzeyEO and TCin components is distinct from that described for the above mentioned anti-TB drugs. Furthermore, it has been suggested that the CzeyEO and Tcin combination exhibits a synergistic effect to enhance the activities of INH and RIF by inhibiting synthesis of mycolic acids and protein, respectively (PALOMINO; MARTIN, 2014).

The mechanism of action of CzeyEO and TCin, specifically related to the hydrophobicity of their components, has already been investigated in several bacteria, but there have been no studies on their mechanism of action in M. tuberculosis. These components of CzeyEO and TCin act primarily on the cytoplasmic membrane, resulting in the altered selective permeability for some ions, altered membrane potential, reduced internal $\mathrm{pH}$, causing loss of proton motive force, membrane rupture, inhibition of the activity of membrane-bound ATPs, and anti-quorum sensing properties (BRACKMAN et al., 2011; YAP et al., 2015).

It is important to mention that all the sensitive and resistant clinical isolates were inhibited by both tested components, demonstrating the absence of intrinsic resistance of $M$. tuberculosis to CzeyEO and TCin, as well as the fact that they were not affected by the mechanisms of resistance to INH, RIF, SM, and EMB. Due to its multiple mechanisms of action in the bacterial cell, studies of resistance or adaptation to CzeyEO have not been described. Therefore, CzeyEO might be used as a potent antibacterial agent.

\section{CONCLUSION}

The antimycobacterial activity of CzeyEO and TCin, as well as the synergistic activities observed with INH and RIF, disclose their potential as candidates for combination therapy against drugresistant M. tuberculosis, as well as a new antimicrobial agent for TB treatment. We suggest studies to evaluate time of exposure through the time kill method, in vitro studies in macrophages and in vivo studies in mice infected with $M$. tuberculosis. We also propose to conduct in vitro cytotoxicity studies in different cell lines and investigate mechanisms of action. 


\section{ACKNOWLEDGEMENTS}

Authors are grateful to the staff of the Dr. Carlos Alberto Studart Gomes Hospital, to the
Herbarium, and to the Laboratory of Mycobacteria of the Federal University of Ceará, for their help and guidance.

RESUMO: O óleo essencial (EO) extraído da casca do Cinnamomum zeylanicum (CzeyEO), conhecido como canela, tem como seu principal composto o trans-cinamaldeído (TCin). O presente estudo avaliou a atividade antimicobacteriana de CzeyEO e do TCin contra isolados clínicos sensíveis e resistentes de Mycobacterium tuberculosis, bem como os efeitos das associações de CzeyEO e do TCin com os fármacos anti-TB, rifampicina (RIF) e isoniazida (INH). A técnica de ensaio de microtitulação da resazurina foi utilizada para determinar a concentração inibitória mínima (CIM) dos componentes testados nos isolados clínicos de $M$. tuberculosis. Os efeitos das associações CzeyEO/RIF, CzeyEO/INH, TCin/RIF e TCin/INH contra a cepa de referência H37Rv de M. tuberculosis foram avaliados pelo método Checkerboard, determinando o índice de concentração inibitória fracionária (ICIF). Todos os isolados clínicos bacterianos foram inibidos por CzeyEO e TCin. As interações de CzeyEO e TCin foram altamente eficazes na redução da resistência do M. tuberculosis resistente a RIF e INH. Todas as quatro combinações testadas resultaram em efeitos sinérgicos e aditivos, sem efeito antagônico. Ambas as associações de sinergismo de CzeyEO/RIF e CzeyEO/INH mostraram valores de ICIF de 0,375 e 0,5 , enquanto as associações de TCin/RIF e TCin/INH apresentaram valores de ICIF de 0,31 e 0,5. CzeyEO e TCin são potenciais candidatos em terapia combinada com INH e RIF para o tratamento da tuberculose resistente.

PALAVRAS-CHAVE: Mycobacterium tuberculosis. Cinnamomum zeylanicum. trans-Cinamaldeído. Tuberculose. Agente antibacteriano.

\section{REFERENCES}

ADAMS, R. Identification of Essential Oil Components by Gas Chromatography/Mass Spectrometry. 4th. Illinois, USA: Allured Publishing Corporation, 2004. 804 p.

ANDRADE-OCHOA, S.; CHACÓN-VARGAS, F.; NEVAREZ-MOORILLON, G.; RIVERA-CHAVIRA, B.; HERNÁNDEZ-OCHOA, L. Evaluation of antimycobacterium activity of the essential oils of cumin (Cuminum cyminum), clove (Eugenia caryophyllata), cinnamon (Cinnamomum verum), laurel (Laurus nobilis) and anis (Pimpinella anisum) against Mycobacterium tuberculosis. Advances in Biological Chemistry, v. 3, n. 5, p. 480-483, 2013. https://doi.org/10.4236/abc.2013.35052

ANDRADE-OCHOA, S.; NEVAREZ-MOORILLON, G. V.; SANCHEZ-TORRES, L. E.; VILLANUEVAGARCIA, M.; SANCHEZ-RAMIREZ, B. E.; RODRIGUEZ-VALDEZ, L. M.; RIVERA-CHAVIRA, B. E. Quantitative structure-activity relationship of molecules constituent of different essential oils with antimycobacterial activity against Mycobacterium tuberculosis and Mycobacterium bovis. BioMed Central Complementary and Alternative Medicine v. 15, p. 332-341, 2015. https://doi.org/10.1186/s12906-015$0858-2$

ANDRADE, M. A.; CARDOSO, M. D. G.; BATISTA, L. R.; MALLET, A. C. T.; MACHADO, S. M. F. Óleos essenciais de Cymbopogon nardus, Cinnamomum zeylanicum e Zingiber officinale: composição, atividades antioxidante e antibacteriana. Revista Ciência Agronômica, v. 43, n. 2, p. 399-407, 2012.

ARO, A. O.; DZOYEM, J. P.; ELOFF, J. N.; MCGAW, L. J. Extracts of six Rubiaceae species combined with rifampicin have good in vitro synergistic antimycobacterial activity and good anti-inflammatory and antioxidant activities. BioMed Central Complementary and Alternative Medicine v. 16, n. 1, p. 385-392, 2016. https://doi.org/10.1186/s12906-016-1355-y 
BAKKALI, F.; AVERBECK, S.; AVERBECK, D.; IDAOMAR, M. Biological effects of essential oils-a review. Food and Chemical Toxicology, v. 46, n. 2, p. 446-475, 2008.

https://doi.org/10.1016/j.fct.2007.09.106

BASSOLE, I. H.; LAMIEN-MEDA, A.; BAYALA, B.; OBAME, L. C.; ILBOUDO, A. J.; FRANZ, C.; NOVAK, J.; NEBIE, R. C.; DICKO, M. H. Chemical composition and antimicrobial activity of Cymbopogon citratus and Cymbopogon giganteus essential oils alone and in combination. Phytomedicine, v. 18, n. 12, p. 1070-1074, 2011. https://doi.org/10.1016/j.phymed.2011.05.009

BRACKMAN, G.; CELEN, S.; HILLAERT, U.; VAN CALENBERGH, S.; COS, P.; MAES, L.; NELIS, H. J.; COENYE, T. Structure-activity relationship of cinnamaldehyde analogs as inhibitors of AI-2 based quorum sensing and their effect on virulence of Vibrio spp. PLoS One, v. 6, n. 1, p. e16084-e16093, 2011.

https://doi.org/10.1371/journal.pone.0016084

CAMACHO-CORONA, M. D. R.; RAMIREZ-CABRERA, M. A.; SANTIAGO, O. G.; GARZAGONZALEZ, E.; PALACIOS, I. P.; LUNA-HERRERA, J. Activity against drug resistant-tuberculosis strains of plants used in Mexican traditional medicine to treat tuberculosis and other respiratory diseases.

Phytotherapy Research, v. 22, n. 1, p. 82-85, 2008. https://doi.org/10.1002/ptr.2269

CHEN, F. C.; PENG, C. F.; TSAI, I. L.; CHEN, I. S. Antitubercular constituents from the stem wood of Cinnamomum kotoense. Journal of Natural Products, v. 68, n. 9, p. 1318-1323, 2005.

https://doi.org/10.1021/np0580210

CHEN, Y. L.; HUANG, S. T.; SUN, F. M.; CHIANG, Y. L.; CHIANG, C. J.; TSAI, C. M.; WENG, C. J. Transformation of cinnamic acid from trans- to cis-form raises a notable bactericidal and synergistic activity against multiple-drug resistant Mycobacterium tuberculosis. European Journal of Pharmaceutical Sciences, v. 43, n. 3, p. 188-194, 2011. https://doi.org/10.1016/j.ejps.2011.04.012

CLSI. Susceptibility Testing of Mycobacteria, Nocardiae, and Other Aerobic Actinomycetes; Approved Standard - Second Edition. Wayne, USA: Clinical and Laboratory Standards Institute, 2011. 72 p. ISBN 156238-746-4.

FERRO, T. A.; ARAUJO, J. M.; DOS SANTOS PINTO, B. L.; DOS SANTOS, J. S.; SOUZA, E. B.; DA SILVA, B. L.; COLARES, V. L.; NOVAIS, T. M.; FILHO, C. M.; STRUVE, C.; CALIXTO, J. B.; MONTEIRO-NETO, V.; DA SILVA, L. C.; FERNANDES, E. S. Cinnamaldehyde Inhibits Staphylococcus aureus Virulence Factors and Protects against Infection in a Galleria mellonella Model. Frontiers in Microbiology v. 7, p. 2052-2051, 2016. https://doi.org/10.3389/fmicb.2016.02052

FONSECA, J. D.; KNIGHT, G. M.; MCHUGH, T. D. The complex evolution of antibiotic resistance in Mycobacterium tuberculosis. International Journal of Infectious Diseases, v. 32, p. 94-100, 2015. https://doi.org/10.1016/j.ijid.2015.01.014

FORRELLAD, M. A.; KLEPP, L. I.; GIOFFRE, A.; SABIO Y GARCIA, J.; MORBIDONI, H. R.; DE LA PAZ SANTANGELO, M.; CATALDI, A. A.; BIGI, F. Virulence factors of the Mycobacterium tuberculosis complex. Virulence, v. 4, n. 1, p. 3-66, 2013. https://doi.org/10.4161/viru.22329

FRANZBLAU, S. G.; WITZIG, R. S.; MCLAUGHLIN, J. C.; TORRES, P.; MADICO, G.; HERNANDEZ, A.; DEGNAN, M. T.; COOK, M. B.; QUENZER, V. K.; FERGUSON, R. M.; GILMAN, R. H. Rapid, lowtechnology MIC determination with clinical Mycobacterium tuberculosis isolates by using the microplate Alamar Blue assay. Journal of Clinical Microbiology, v. 36, n. 2, p. 362-366, 1998. 
GOMEZ, J. V.; TARAZONA, A.; MATEO-CASTRO, R.; GIMENO-ADELANTADO, J. V.; JIMENEZ, M.; MATEO, E. M. Selected plant essential oils and their main active components, a promising approach to inhibit aflatoxigenic fungi and aflatoxin production in food. Food Additives and Contaminants. Part A, Chemistry, Analysis, Control, Exposure \& Risk Assessment, v. 35, n. 8, p. 1-15, 2018.

https://doi.org/10.1080/19440049.2017.1419287

HOFFMANN, C.; LEIS, A.; NIEDERWEIS, M.; PLITZKO, J. M.; ENGELHARDT, H. Disclosure of the mycobacterial outer membrane: cryo-electron tomography and vitreous sections reveal the lipid bilayer structure. Proceedings of the National Academy of Sciences of the United States of America, v. 105, n. 10, p. 3963-3967, 2008. https://doi.org/10.1073/pnas.0709530105

JIMENEZ-ARELLANES, A.; LUNA-HERRERA, J.; CORNEJO-GARRIDO, J.; LOPEZ-GARCIA, S.; CASTRO-MUSSOT, M. E.; MECKES-FISCHER, M.; MATA-ESPINOSA, D.; MARQUINA, B.; TORRES, J.; HERNANDEZ-PANDO, R. Ursolic and oleanolic acids as antimicrobial and immunomodulatory compounds for tuberculosis treatment. BioMed Central Complementary and Alternative Medicine v. 13, p. 258-267, 2013. https://doi.org/10.1186/1472-6882-13-258

KASULE, G. W.; KATEETE, D. P.; JOLOBA, M. L. Mycobacterium tuberculosis Uganda II is more susceptible to rifampicin and isoniazid compared to Beijing and Delhi/CAS families. BioMed Central Infectious Diseases, v. 16, p. 173-180, 2016. https://doi.org/10.1186/s12879-016-1487-1

LECHARTIER, B.; HARTKOORN, R. C.; COLE, S. T. In vitro combination studies of benzothiazinone lead compound BTZ043 against Mycobacterium tuberculosis. Antimicrobial Agents and Chemotherapy, v. 56, n. 11, p. 5790-5793, 2012. https://doi.org/10.1128/AAC.01476-12

LIU, Q.; MENG, X.; LI, Y.; ZHAO, C. N.; TANG, G. Y.; LI, H. B. Antibacterial and Antifungal Activities of Spices. International Journal of Molecular Sciences, v. 18, n. 6, p. 1283-1345, 2017. https://doi.org/10.3390/ijms18061283

MOTA, A. P. P.; DANTAS, J. C. P.; FROTA, C. C. Antimicrobial activity of essential oils from Lippia alba, Lippia sidoides, Cymbopogon citrates, Plectranthus amboinicus, and Cinnamomum zeylanicum against Mycobacterium tuberculosis. Ciência Rural, v. 48, n. 6, p. 1-9, 2018. https://doi.org/10.1590/0103$8478 \mathrm{cr} 20170697$

NAIK, S. K.; MOHANTY, S.; PADHI, A.; PATI, R.; SONAWANE, A. Evaluation of antibacterial and cytotoxic activity of Artemisia nilagirica and Murraya koenigii leaf extracts against mycobacteria and macrophages. BioMed Central Complementary and Alternative Medicine v. 14, p. 87-96, 2014. https://doi.org/10.1186/1472-6882-14-87

NATIONAL TOXICOLOGY, P. NTP toxicology and carcinogenesis studies of trans-cinnamaldehyde (CAS No. 14371-10-9) in F344/N rats and B6C3F1 mice (feed studies). National Toxicology Program Technical Report Series, n. 514, p. 1-281, 2004.

ODDS, F. C. Synergy, antagonism, and what the chequerboard puts between them. Journal of Antimicrobial Chemotherapy v. 52, n. 1, p. 1, 2003. https://doi.org/10.1093/jac/dkg301

OKOH, S. O.; ASEKUN, O. T.; FAMILONI, O. B.; AFOLAYAN, A. J. Composition and antioxidant activities of leaf and root volatile oils of Morinda lucida. Natural Product Communications, v. 6, n. 10, p. 1537-1541, 2011.

PALOMINO, J. C.; MARTIN, A. Drug Resistance Mechanisms in Mycobacterium tuberculosis. Antibiotics (Basel), v. 3, n. 3, p. 317-340, 2014. https://doi.org/10.3390/antibiotics3030317 
PALOMINO, J. C.; MARTIN, A.; CAMACHO, M.; GUERRA, H.; SWINGS, J.; PORTAELS, F. Resazurin microtiter assay plate: simple and inexpensive method for detection of drug resistance in Mycobacterium tuberculosis. Antimicrobial Agents and Chemotherapy, v. 46, n. 8, p. 2720-2722, 2002.

https://doi.org/10.1128/AAC.46.8.2720-2722.2002

PERRICONE, M.; ARACE, E.; CORBO, M. R.; SINIGAGLIA, M.; BEVILACQUA, A. Bioactivity of essential oils: a review on their interaction with food components. Front Microbiol, v. 6, p. 76-82, 2015. https://doi.org/10.3389/fmicb.2015.00076

POLAQUINI, C. R.; TORREZAN, G. S.; SANTOS, V. R.; NAZARE, A. C.; CAMPOS, D. L.; ALMEIDA, L. A.; SILVA, I. C.; FERREIRA, H.; PAVAN, F. R.; DUQUE, C.; REGASINI, L. O. Antibacterial and Antitubercular Activities of Cinnamylideneacetophenones. Molecules, v. 22, n. 10, p. 1685-1686, 2017. https://doi.org/10.3390/molecules22101685

RANA, I. S.; SINGH, A.; GWAL, R. In vitro study of antibacterial activity of aromatic and medicinal plants essential oils with special reference to cinnamon oil. International Journal of Pharmacy and Pharmaceutical Sciences, v. 3, n. 4, p. 376-380, 2011.

RASTOGI, N.; GOH, K. S.; HORGEN, L.; BARROW, W. W. Synergistic activities of antituberculous drugs with cerulenin and trans-cinnamic acid against Mycobacterium tuberculosis. FEMS Immunology and Medical Microbiology, v. 21, n. 2, p. 149-157, 1998.

RAVINDRAN, P. N.; NIRMAL-BABU, K.; SHYLAJA, M. Cinnamon and Cassia. The Genus Cinnamomum. Florida: CRC Press, 2003. 384 p.

ROSATO, A.; VITALI, C.; DE LAURENTIS, N.; ARMENISE, D.; MILILLO, M. A. Antibacterial effect of some essential oils administered alone or in combination with Norfloxacin. Phytomedicine, v. 14, n. 11, p. 727-732, 2007. https://doi.org/10.1016/j.phymed.2007.01.005

SINGH, S.; KUMAR, P.; SHARMA, S.; MUMBOWA, F.; MARTIN, A.; DURIER, N. Rapid Identification and Drug Susceptibility Testing of Mycobacterium tuberculosis: Standard Operating Procedure for NonCommercial Assays: Part 3: Colorimetric Redox Indicator Assay v1.3.12. Journal of Laboratory Physicians, v. 4, n. 2, p. 120-126, 2012. https://doi.org/10.4103/0974-2727.105594

TAHA, A. M.; ELDAHSHAN, O. A. Chemical Characteristics, Antimicrobial, and Cytotoxic Activities of the Essential Oil of Egyptian Cinnamomum glanduliferum Bark. Chemistry and Biodiversity, v. 14, n. 5, p. e1600443, 2017. https://doi.org/10.1002/cbdv.201600443

UTCHARIYAKIAT, I.; SURASSMO, S.; JATURANPINYO, M.; KHUNTAYAPORN, P.; CHOMNAWANG, M. T. Efficacy of cinnamon bark oil and cinnamaldehyde on anti-multidrug resistant Pseudomonas aeruginosa and the synergistic effects in combination with other antimicrobial agents. BioMed Central Complementary and Alternative Medicine v. 16, p. 158-164, 2016. https://doi.org/10.1186/s12906016-1134-9

VAIDYA, S.; SHARMA, J.; MANIAR, J.; PRABHU, N.; MAMAWALA, M.; JOSHI-PUNDIT, S.; CHOWDHARY, A. Assessment of anti-tuberculosis activity of extracts of Cinnamomum verum and solanun surattense along with isoniazid. European Respiratory Journal, v. 48, n. suppl 60, p. PA2691, 2016. https://doi.org/10.1183/13993003.congress-2016.PA2691

WALLIS, R. S.; MAEURER, M.; MWABA, P.; CHAKAYA, J.; RUSTOMJEE, R.; MIGLIORI, G. B.; MARAIS, B.; SCHITO, M.; CHURCHYARD, G.; SWAMINATHAN, S.; HOELSCHER, M.; ZUMLA, A. Tuberculosis-advances in development of new drugs, treatment regimens, host-directed therapies, and biomarkers. The Lancet. Infectious diseases, v. 16, n. 4, p. e34-46, 2016. https://doi.org/10.1016/S14733099(16)00070-0 
WHO. Global tuberculosis report 2017. 2017. 147 p. Disponível em: < http://www.who.int/tb/publications/global_report/en/ >.

WIWATTANARATTANABUT, K.; CHOONHARUANGDEJ, S.; SRITHAVAJ, T. In Vitro Anti-Cariogenic Plaque Effects of Essential Oils Extracted from Culinary Herbs. Journal of Clinical and Diagnostic Research, v. 11, n. 9, p. DC30-DC35, 2017. https://doi.org/10.7860/jcdr/2017/28327.10668

YAP, P. S.; KRISHNAN, T.; CHAN, K. G.; LIM, S. H. Antibacterial Mode of Action of Cinnamomum verum Bark Essential Oil, Alone and in Combination with Piperacillin, Against a Multi-Drug-Resistant Escherichia coli Strain. Journal of Microbiology and Biotechnology, v. 25, n. 8, p. 1299-1306, 2015.

https://doi.org/10.4014/jmb.1407.07054 